\title{
IDEOLOGICAL FOUNDATIONS AND CULTURAL MANIFESTA- TIONS OF YOUTH VOLUNTEERING IN ARMENIA
}

\author{
HARUTYUN VERMISHYAN, TATYANA DARBINYAN
}

\section{Introduction}

Modern tendencies of individualization strongly emphasize the importance of sociological studies of such altruistic practices as volunteering ${ }^{1}$. Volunteer work or volunteering is the reproduction of the core values of civil society and a significant manifestation of social integration, participation, and inclusion ${ }^{2}$. The circumstantial research of volunteering practices is a key to understand the development of civil society and the level of civil consciousness. In other words, any individual act of volunteering can be seen as a part of both broader social context and broader social structures ${ }^{3}$.

One of the outstanding developments at the end of the $20^{\text {th }}$ century and the beginning of the $21^{\text {st }}$ century is the globalization of volunteering practices, "a massive upsurge of organized, private, voluntary activity in virtually every region of the world"'. The globalization of volunteering was declared in November 1997, when the United Nations General Assembly conducted a resolution declaring 2001 the International Year of Volunteers ${ }^{5}$. In recent decades volunteering as a civil practice and ideology obtain specific manifestations in the context of post-Soviet transformations ${ }^{6}$. Armenia in terms of the spread of volunteering practices occupies a special place among the post-Soviet republics in South Caucasus ${ }^{7}$. According to the data collected

${ }^{1}$ See Wilson J. and Musick M. A. (1997) Who Cares? Toward an Integrated Theory of Volunteer Work, American Sociological Review, Vol. 62, No. 5, pp. 694-713; Wilson J. (2000) Volunteering, Annual Review of Sociology, 26; Wilson J. and Musick M. A. (2008) Volunteers. A Social Profile, Indiana University Press, pp. 217-399; Hustinx L., Cnaan R. A., Handy F., (2010) Navigating Theories of Volunteering: A Hybrid Map for a Complex Phenomenon, Journal for the Theory of Social Behaviour, pp. 414-418.

${ }^{2}$ See Wilson J. and Musick M. A. (2008) Volunteers. A Social Profile, Indiana University Press pp. 459-485; Strauß S. (2008) Volunteering and Social Inclusion, 1st Edition, Edited by Prof. Dr. Steffen Hillmert, University of Tübingen, Germany.

${ }^{3}$ See Piliavin J. A., Grube J. A., Callero P. L. (2002) Role as Resource for Action in Public Service, Journal of Social Issues, Vol. 58, No. 3, pp. 469-485.

${ }^{4}$ See Salamon L. M., Sokolowski S. W., List R. (2003) Global Civil Society: An Overview, John Hopkins Comparative Nonprofit Sector Project.

${ }_{5}$ Un General Assembly Resolution (A/RES/52/17), November 20, 1997, available at: https:// www.unv.org/Publications/UNGA-Resolution-5217-Declaration-2001-International-Year-Volunteers

6 Juknevičius S., Savicka A. (2003) From restitution to innovation: Volunteering in postcommunist countries, in P. Dekker and L. Halman (eds) The values of volunteering: Crosscultural perspectives, New York, NY: Springer, pp. 127-142; Howard M.M. (2003) The weakness of civil society in post-communist Europe, Cambridge: Cambridge University Press.

7 See Gevorgyan V., Galstyan M. (2016) Why Volunteer? Understanding Armenia's Experience Voluntary Sector Review. Vol.7. Number 3; Paturyan Y., Gevorgyan V. Volunteering in Armenia: Leaving the Soviet Legacy Behind? in Butcher J., Einolf Ch. J. (2017) Perspectives on Volunteering: Voices from the South: Springer, pp. 227-244; Paturyan Y., Gevorgyan V. (2014) 
in 2011-2019, Armenia has a greater level of self-reported volunteering than its neighboring state Georgia ${ }^{8}$. More precisely, in 2011, 2015, and 2019 the levels of volunteering in Armenia were 22\%, 37\%, and 30\% respectively ${ }^{9}$. The demographic component is central in volunteering studies and analysis ${ }^{10}$. According to research the levels of trust towards NGOs and self-reported volunteering in Armenia significantly vary in different age groups: (1) youth is more likely to trust NGOs, (2) there is a statistically significant relationship between the level of volunteering activity and age, which is the result of not only high levels of youth volunteering but also the very low level of older generation's engagement in volunteer work ${ }^{11}$.

The purpose of this article is to present the ideological and cultural aspects of youth volunteering in Armenia constructing the narratives of volunteer work engagement and volunteering experience. Young volunteers aged 18-35 living in Armenia are considered to be the essential elements of the current study.

\section{Theoretical background and methodological approach}

The ideological and cultural aspects of volunteering include how people attach meaning to volunteering (cognitive or conscious dimensions of subjectivity) and how people actually volunteer (nonconscious dimensions of subjectivity) ${ }^{12}$. Guided from a Sociological point of view volunteering can be studied in terms of Max Weber's theory of social action. According to this approach, volunteering can be defined as social action which is subjectively meaningful and involves a relation to another person's behavior $^{13}$. Following Weber's approach, four main types of volunteering can be defined: rationally-purposeful, value-rational, traditional, and affective.

Studying volunteering from Weber's methodological position we make a shift to the sphere of rational - non-rational opposition. Thus, it becomes central to figure out the subjective meanings of volunteers in the context of volunteering motivations. Meanwhile, volunteering should be studied as a process. By way of explanation, volunteering is a process embedded in an individual's lived experience $^{14}$. And so, the studies of volunteering experience and volunteering narratives become principal.

Trust towards NGOs and volunteering in South Caucasus: civil society moving away from postcommunism? Southeast European and Black Sea Studies, 14:2, pp. 239-262.

${ }^{8}$ See Activities during last 6 months: Volunteered without expecting compensation. Caucasus Research Resource Centers, (2011-2019), Caucasus Barometer [datasets]. Available at:https://caucasusbarometer.org/am/cb2019/ACTVLNT/

${ }_{9}$ See Activities during last 6 months: Volunteered without compensation. Caucasus Research Resource Centers, (2011-2019), Caucasus Barometer [datasets]. Available at:https://caucasusbarometer.org/am/cb-am/ACTVLNT/

${ }_{11}^{10}$ See Wilson J. (2000) Volunteering, Annual Review of Sociology, 26, p. 226.

11 See Paturyan Y., Gevorgyan V. (2014) Trust towards NGOs and volunteering in South Caucasus: civil society moving away from post-communism? Southeast European and Black Sea Studies, 14:2, pp. 239-262.

${ }^{12}$ See Wright E.O. (2002) Sociology 298, Lecture 11: Class Analysis of Ideology, available at: https://www.ssc.wisc.edu/ wright/SOC621/298lec11.pdf.

${ }_{13}$ See Weber M. (1956) The Nature of Social Action, Economy and Society 4th edn, Tubingen, First published in 1922.

${ }^{14}$ See Hustinx L., Cnaan R. A., Handy F., (2010) Navigating Theories of Volunteering: A Hybrid Map for a Complex Phenomenon, Journal for the Theory of Social Behaviour, p. 413. 
In the course of research planning an operational scheme of volunteering as social action was designed first. The classical functional model of volunteering motivations was used in order to define the types of social action in relation to volunteer work. The mentioned classification model identifies six types of volunteering functions: values, understanding, career, social, protective, and enhancement ${ }^{15}$. Synthesizing and incorporating the functional model with Weber's definition of action types we imply the following: rationally-purposeful action involves career and understanding functions, value-rational action is based on values function, traditional type of social action is parallel to the social function of volunteering, and the affective type can be described with reference to protective and enhancement functions ${ }^{16}$ (see the operational scheme in Figure 1).

\section{Volunteering as social action}

Figure 1

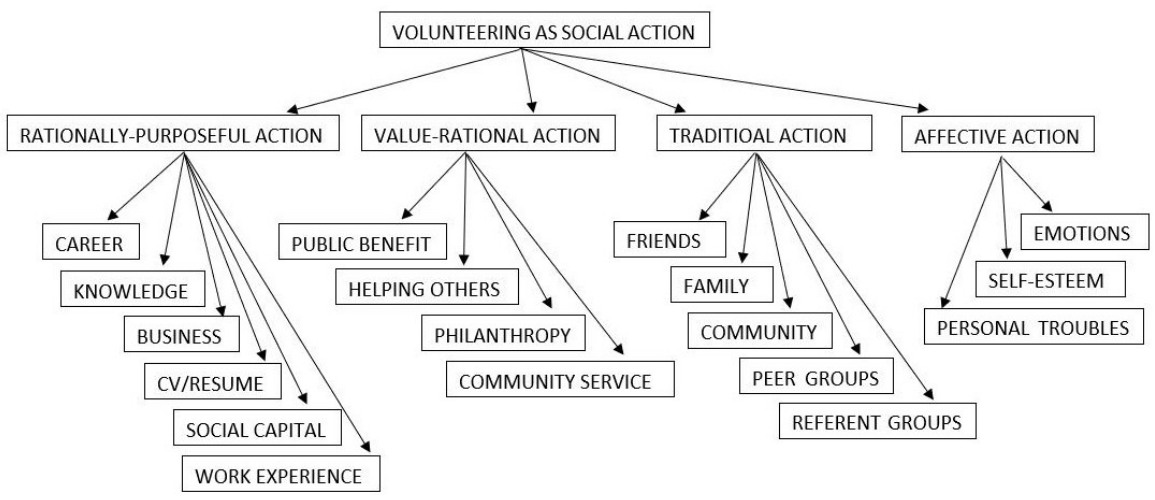

Based on the aforementioned theoretical and methodological approaches we designed and used mixed methods research to find out the ideological and cultural aspects of youth volunteering in Armenia. First, the method of the quantitative interview was applied, which was aimed to identify the types of youth volunteers based on their rationality.

The online instrument for the quantitative interview was composed of localized valid variables ${ }^{17}$ identifying motives of volunteer engagement. The variables were grouped according to the operational scheme introduced above in Figure 1, comprising 5 variables describing each type.

Therefore, indexes corresponding to volunteering motives and meanings were counted in order to figure out the types of volunteers. The calculation of indexes showed that volunteer motives describing traditional and affective types

${ }^{15}$ See Clary E. G., Snyder M., Stukas A. A. (1996) Volunteers' Motivations: Findings from a National Survey Nonprofit and Voluntary Sector Quarterly pp. 485-505; Clary E. G., Snyder M., Ridge R. D., Copeland J., Stukas A. A., Haugen J. and Miene P. (1998) Understanding and Assessing the Motivations of Volunteers: A Functional Approach.

${ }^{16}$ See Clary E. G., Snyder M. (1999) The Motivations to Volunteer: Theoretical and Practical Considerations, Current Directions in Psychological Science, Vol. 8, No. 5, pp. 156-159.

${ }_{17}$ See Clary E. G., Snyder M., Ridge R. D., Copeland J., Stukas A. A., Haugen J. and Miene P. (1998) Understanding and Assessing the Motivations of Volunteers: A Functional Approach. 
were almost nonexistent, while in addition to the rationally-purposeful and the value-rational types there is another fifth type significantly exposed. In that new type, the indexes of both rationally-purposeful and value-rational types are balanced and relatively equal. Hypothetically, we call it the "hybrid" type as a combination of both rationally-purposeful and value-rational types (see Figure 2).

Figure 2

\section{Volunteer types}

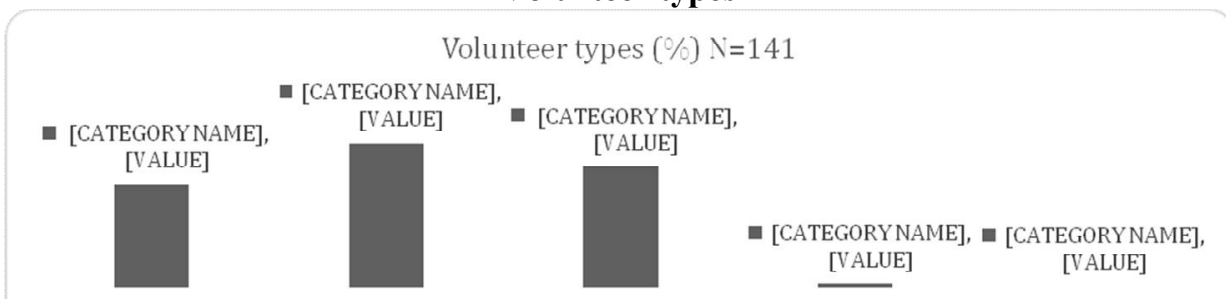

Hence, we discover three basic models of volunteering activity in Armenia: 1. rationally-purposeful, 2. value-rational, 3. hybrid. It becomes possible to identify the ideological dimensions and cultural manifestations of youth volunteering in Armenia. To pursue this objective, the method of the narrative interview was used as the main method of data collection. The application of this method was aimed at constructing the narratives of the volunteering experience. Quota sampling was used for this qualitative method.

Further logic of this research was based on the narratives mentioned above: six narratives of volunteering experience were analyzed.

\begin{tabular}{lll}
\hline Rationally-purposeful & 2 narratives & Participant 1 \\
& & Participant 2 \\
\hline Value-rational & 2 narratives & Participant 3 \\
& & Participant 4 \\
\hline Hybrid & 2 narratives & Participant 5 \\
& & Participant 6 \\
\hline
\end{tabular}

The narratives of volunteering experience were analyzed using the methodology of narrative semiotics. This methodology, developed by French semiotician A. J. Greimas, is a relatively objective approach of experience measurement among the methods of narrative analysis. Within this approach suggested by Greimas a specific model of experience measurement and analysis is constructed by emphasizing the meanings ${ }^{18}$. The specification of three-dimensional narrative structure is the cornerstone of this approach. These composing dimensions are the surface structure, narrative structure, and deep structure ${ }^{19}$.

The whole logic of narrative semiotics is built on the principle of figuring out the deep structure from the surface structure through the analysis of narrative structures. The values and norms are crucial in deep structure. The key to

${ }^{18}$ See Greimas A. J. (1987) On Meaning: Selected Writings in Semiotic Theory, Theory and History of Literature, Volume 38, University of Minnesota Press, Minneapolis; Греймас А. Ж. (2004) Структурная семантика, Поиск Метода. Москва: Академический проект. ст. 25-42.

${ }^{19}$ See Titscher S., Meyer M., Wodak R. and Vetter E. (2000) Methods of Text and Discourse Analysis, Sage, p. 126. 
reveal and understand the deep structure is the semiotic square ${ }^{20}$.

In accordance with the theoretical approaches discussed above the analysis of the deep structure of the narratives of volunteering experience derives from two oppositions: rational - non-rational, egoism - altruism ${ }^{21}$. The altruism egoism opposition can be interpreted with a synonymous opposition of public interest and self-interest.

As it follows, the dominant value of the semiotic square of the deep structure appears to be the public-interest or altruism and its contrary, contradictory and complementary values are self-interest (egoism), non-public-interest (nonaltruism) and non-self-interest (non-egoism).

Contemporaneously, rational - non-rational opposition is based on the conceptualization of four types of social action. The core concepts peculiar to these action types are values, goals, traditions, and emotions. These concepts are comparable to the mentioned contrary, contradictory, and complementary pairs of semiotic values. And so, the semiotic pole of public interest involves values (value-rational action), self-interest is parallel to goals (rationallypurposeful action), non-self-interest is described by traditions (traditional action) and finally, the semiotic area of non-public interest involves emotions (affective action). Accordingly, the sphere of rational action implies publicinterest - self-interest opposition, and the non-public-interest - non-self-interest contrary pair is located in the non-rational semiotic sphere.

Keeping with this logic the analysis of the deep structure of volunteering experience narratives was carried out using the semiotic square (see Figure 3).

\section{Semiotic square of deep structure}

Figure 3

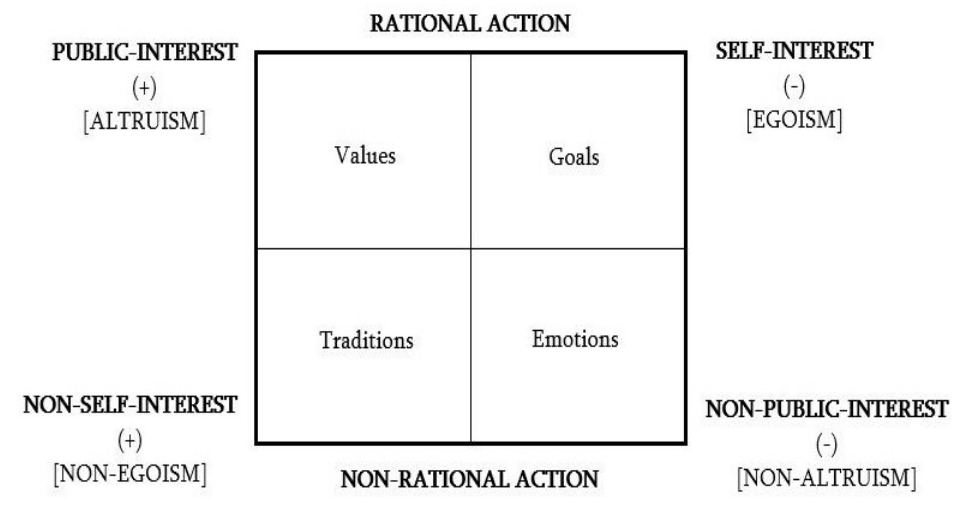

${ }^{20}$ See Fiol M. C. (1989) A Semiotic Analysis of Corporate Language: Organizational boundaries and Joint Venturing, Administrative Science Quarterly, Vol. 34, No 2, pp. 277-303.

${ }^{21}$ See Wilson J. and Musick M. A. (2008) Volunteers. A Social Profile, Indiana University Press, p. 65. 


\section{The main findings}

Based on the online survey the specification of three types of volunteers, and hence the exception of two types of Weberian classification (traditional and affective) highlights the rational dimension of meaning attached to volunteering by the respondents.

After figuring the surface structure of narratives summarizing the volunteering experience of youth, two stages were analyzed: (1) before volunteering or the beginning of volunteering, (2) the continued process of volunteering.

From the narrative structure analysis point of view, the forces and relations of narrative have been considering their mode (cognitive or pragmatic) and tone (negative or positive) $^{22}$.

The revelation of narrative structures with their specific relations serves as a basis to claim that the ideological and cultural practices of volunteering involvement are shaped by volunteer - team, volunteer - community, volunteer family, volunteer - organization, volunteer - beneficiary relations. Furthermore, the negative sanctioning of volunteering is more frequently demonstrated by family or community: more often they have negative tonality. As for the NGOs, in a number of cases, they appear as "volunteer exploiters" or "non-proper policy conductors" in the context of volunteer engagement.

The details on both the narrative and deep structures of the interviews are discussed below.

\section{Rationally-purposeful type}

In two narratives characterizing this type the intention to gain knowledge, experience, social capital, and career opportunities is the explicit orientation at the stage of decision making. They appear as forces having cognitive mode and positive tone.

“As long as I graduated my Bachelor's Degree, I had already a burning desire to find a job, but I strongly believed I could not find a job with my major, I considered doing volunteer work first, and then finding a job" (Participant 1).

It is not worthy that alongside career perspectives the impact of referent groups is also noticeable here.

"My main goal was not to refuse my lecturer to go there, secondly, I could use it, I had my interest” (Participant 2).

In these narratives, the "public benefit" becomes considerable in the second stage. What is more, in one of the interviews it gains cognitive and positive expression, while in another one its manifestation is both cognitive and negative.

"The Armenian Red Cross Society was a serious obligation. You should decide whether you want to do it. It required some devotion, it had some moments,

${ }^{22}$ See Fiol M. C. (1989) A Semiotic Analysis of Corporate Language: Organizational boundaries and Joint Venturing, Administrative Science Quarterly, Vol. 34, No 2, pp. 277-303; Titscher S., Meyer M., Wodak R. and Vetter E. (2000) Methods of Text and Discourse Analysis, Sage, pp. 129-130. 
visits to refugees and so, many such problematic things. I thought she was able to do it due to her profession, but I didn't want to immerse myself in such things, in order to avoid negative elements to enter my life" (Participant 1).

or

"I was happy that I could help them with something, and especially it was in the sphere of education and I became very happy when I saw that it really helped... And when we saw the real results, for example, what they did in schools, etc., then we were also excited, and regardless of everything we wanted to change something" (Participant 2).

The team of other volunteers never gains a positive tone in both interviews. Moreover, it has both cognitive and negative implications in the narrative of Participant 1.

"And yes, what was the problem with it? That everything was presented as the work of the whole (team), for that reason I got nervous" (Participant 2).

Thus, going beyond the narrative structure towards the deep structure we summarize that in the deep structure of rationally-purposeful type in both first and second stages the self-interest is dominant (see Figure 4). In the second stage, it's vividly seen some ideological practices of "making some change", "bringing some benefit to the public", "helping others", however, the dominance of self-interest or dominance of goals remains substantial.

Figure 4

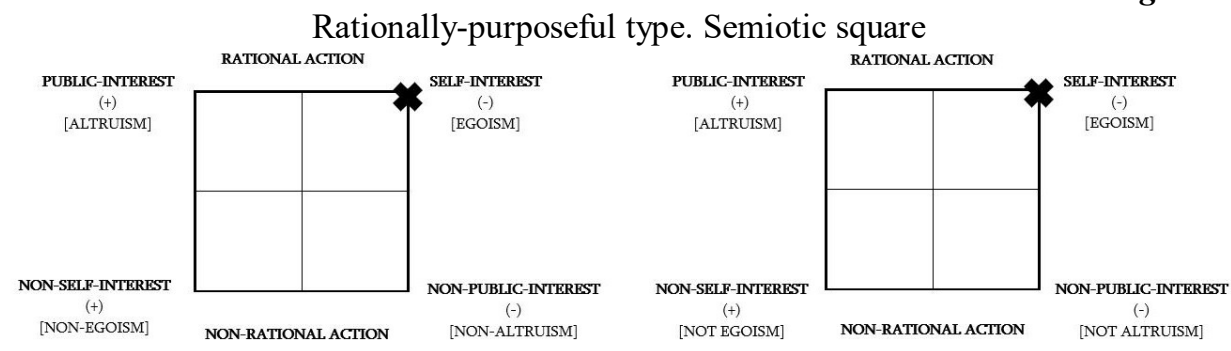

Value-rational type

In narratives characterizing the value-rational type situational orientations are central in the decision-making stage.

"And very surprisingly a girl jumped out of a room, and it was interesting, we asked, some whispers were heard, as who the girl was, what she was doing, and so such whispers. I found out that she was a volunteer. And then, "volunteer?", "well, what do they do?", such confusing thoughts, because just like the social center was new for us, the same was volunteering" (Participant 3).

In this case, the representative of the referent group gains positive tonality (both cognitive and pragmatic) in one of the narratives.

"I had my first experience in the social-educational center of Armenian Apostolic Diocese at the request of the Head of our Chair Mr. Ghukasyan ... He accompanied us, we went to the meeting, then he offered that I tried to start my experience from volunteering" (Participant 4). 
In both narratives, the community and even the peer groups are expressed in negative relations.

"During the whole period that I was engaged in volunteering programs, there was always something like a red line, for everyone: "Well, why are you doing that?" Such a question passes like a red line: how can one work without money? And no one, in no nobody's thoughts there were other versions apart from the idea, that you are a fool, that you are abused, you are exploited" (Participant 3)

Parallel to the community, the family also becomes a narrative force having negative implications. Therefore, in these narratives community and family sanction volunteering activity in a negative manner.

What concerns volunteer-beneficiary, and volunteer-team relations they both bear a positive tone in the experience of value-rational volunteers. NGOs are also expressed in these narrative structures getting negative emphasis periodically.

"I mean I had imagined completely different things regarding an NGO, its activity, its goals, and something else became apparent, which was miserable. I'm sorry, I will not put the cards on the table" (Participant 3).

\section{Hybrid type}

The decision-making stage in narratives of the third type is very similar to the narratives of the value-rational type. For this type, the beginning of volunteering engagement can be characterized by its situational and accidental nature, either. In addition, like value-rational narratives, the hybrid type also shows the negative tone of community and peer groups in narrative relations.

"Very often a friend of mine came and asked "Where are you going, what a pity, you do such things, you call one another "friend", (Participant 6).

Along the same lines, the family also obtains a negative tone.

"Hmm, maybe the first was by the family, not a pressure, but the disturbance of my family members, especially of my father, because most of all I thought I would come late again and Dad would be annoyed. And every time I said to myself "Ok, it is the last time. ... if you finish volunteering you will not be distracted by anything” (Participant 5).

It's necessary to state that in both narratives of hybrid type the intention to gain knowledge, skills, or experience is primarily absent. However, in the second stage, it is expressed as a helping force in further continued volunteering. In these interviews, NGOs are present on a cognitive-negative level.

"I just got disappointed with that all. I don't say that the money should have been paid to me, I say that the money should have been paid to that volunteer in a proper manner, which the volunteer was not even aware of, that he had such an amount to be paid. Therefore, we had many omissions in the NGO sphere, which I saw, I myself experienced" (Participant 5). 
or

"Simply I have an inner problem with them because they do volunteer work for money. They take ten thousand. They offer their volunteering services to some organizations, they say "You can pay for each volunteer ten thousand, and we would provide you a certain number of volunteers" (Participant 5).

It becomes apparent that the volunteering narratives of value-rational and hybrid types are similar in a considerable manner with regard to the plot development and the dynamics of deep structure transformation through stages (see Figure 5 and 6).

Figure 5

\section{Values-rational type. Semiotic square}
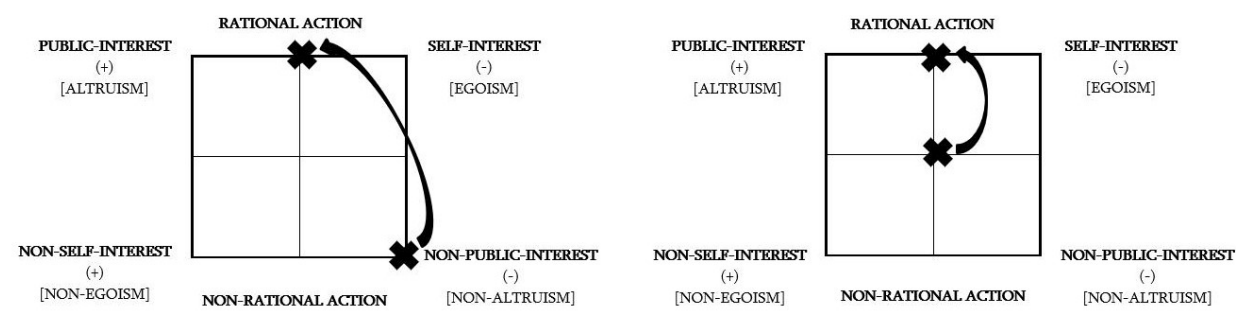

Hybrid type. Semiotic square
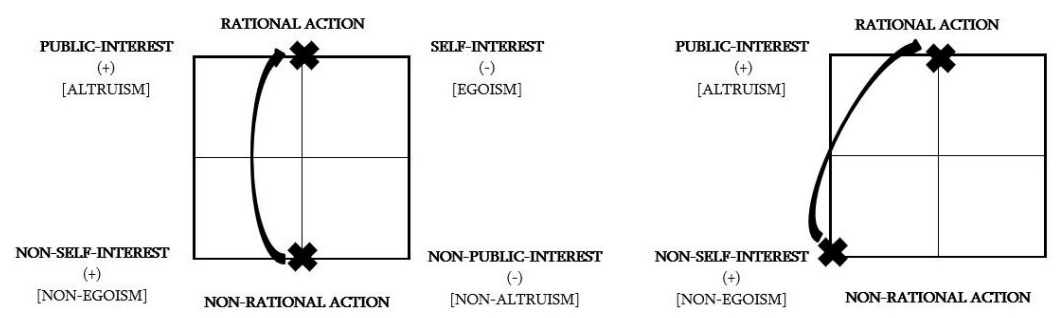

Figure 6

In all four interviews, the deep structure of the narratives of volunteering experience terminates in the upper border of the semiotic square getting a position between public interest and self-interest or between values and goals. Meanwhile, in the first stage, the picture is completely different in all narratives.

In the beginning, the practices of engagement actually possess non-rational nature being located in tradition - emotion or non-public-interest - non-selfinterest semiotic sphere. However, as a consequence of the volunteering process, the ideological and cultural practices are moved towards the rational sphere coming to an end in values - goals border.

For all the narratives the final points characterizing volunteer experience are two specific points of the semiotic square (see Figure 7). 


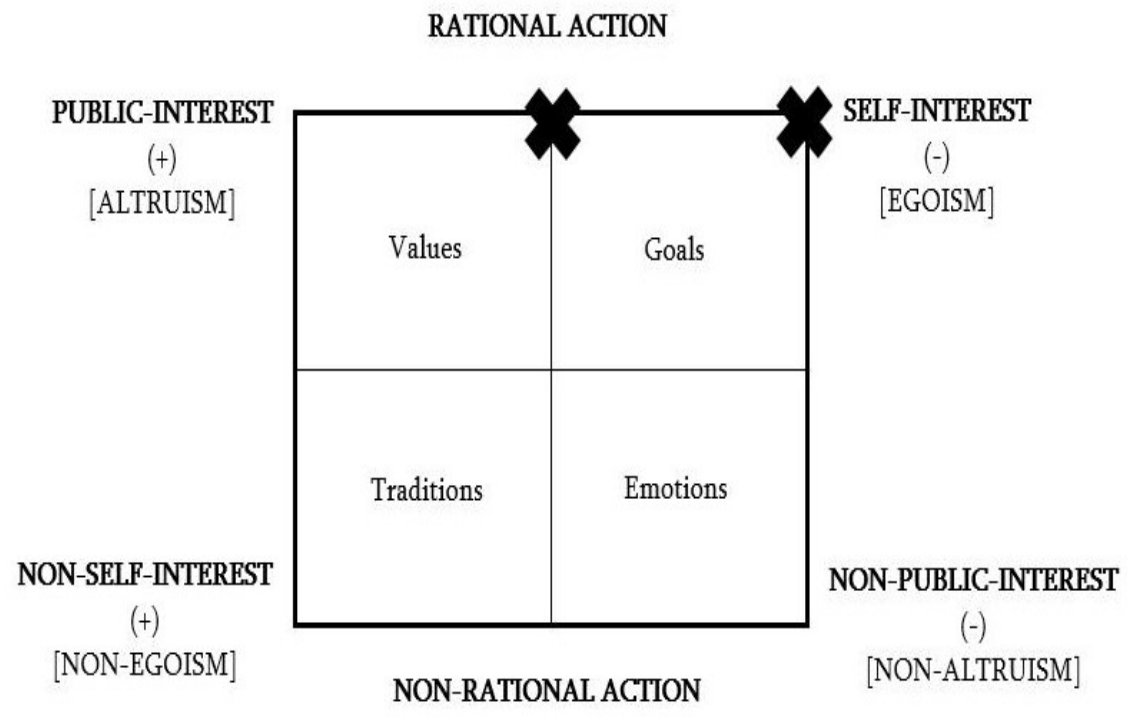

\section{Conclusion and discussion}

With reference to the analysis introduced above, it can be argued that the practices of involvement in volunteering activities (decision-making stage) have features analogous to rationally-purposeful, affective, and traditional types of social action, the ideological foundations of which are in the sphere of selfinterest - non-public-interest - non-self-interest in the semiotic square.

Parallel to the process of volunteering activity, the practices are transformed obtaining exceptionally rational character. Here the ideological and cultural aspects are in the sphere of goals-values. The final points in the four narratives are somewhere around the self-interest semiotic sphere: goals are always existent and principal (see Figure 7).

Therefore, it can be claimed that the ideological dimensions and cultural manifestations of youth volunteering in Armenia are rational, defined either by the mere prevalence of self-interest (goals) or by the combination of selfinterest with the public interest (goals plus values).

In fact, the studies of volunteering in modern societies can be taken as the empirical indicators of the level of civil society development. From this perspective, the revelation of the deep structures of volunteering narratives of Armenian youth demonstrates that the volunteering engagement of Armenian youth is not characterized by the dominance of public interest or values, which appears to be the core emphasis of civil ideology. At the beginning of volunteering or in the stage of decision making apart from the rationally purposeful social 
action the features attributed to affective and traditional action types are displayed. However, further analysis suggests that the continuation of volunteering strongly requires some rational base. The rational nature of volunteering engagement (the predominance of rationally-purposeful action type or its combination with value-rational features) is shaped by the impact of community, family, peer groups, and NGOs.

In summary, the evidence from this study points towards the idea that generally Armenian youth's engagement in volunteering activities does not appear to be a manifestation of citizenship, civil engagement, civil values, and ideology, but more substantially it appears to be a "rational strategy" or "rational mechanism" to accomplish certain goals and objectives.

Keywords: ideology, culture, youth, volunteering, value-rational action, rationallypurposeful action, narrative semiotics

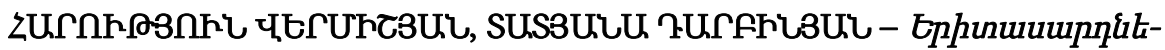

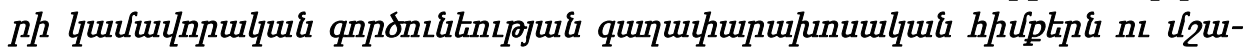

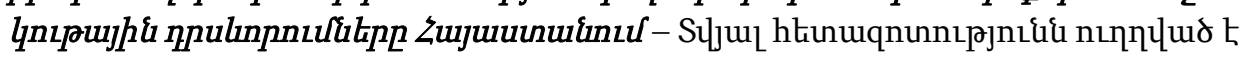

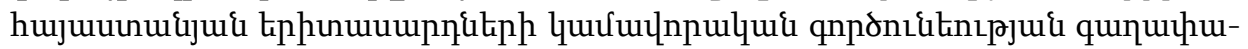

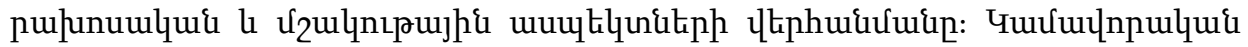

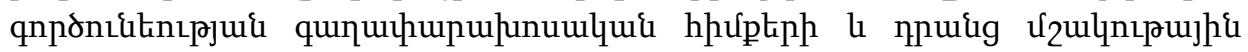

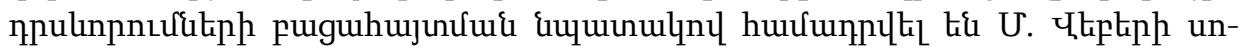

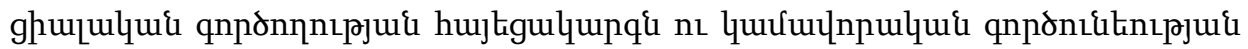

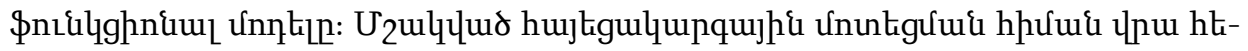

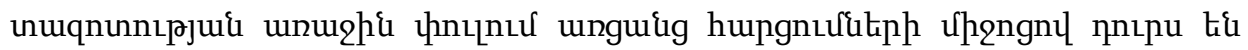

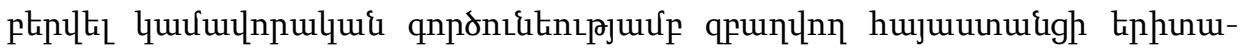

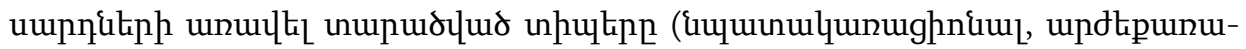

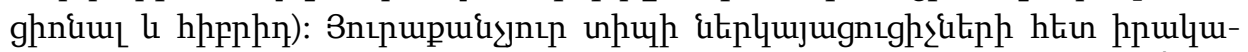

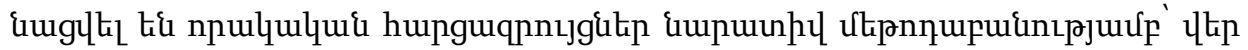

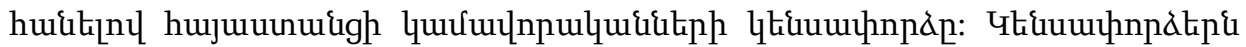

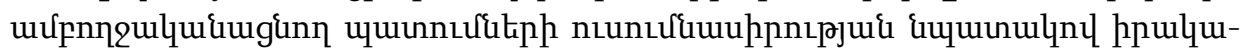

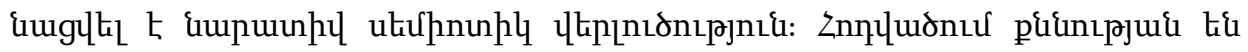

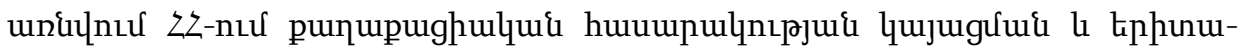

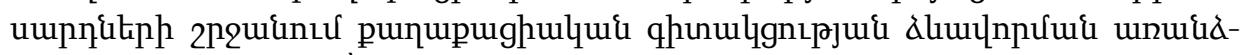

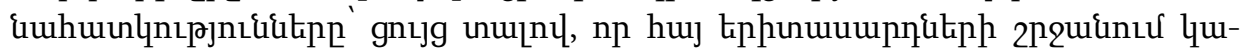

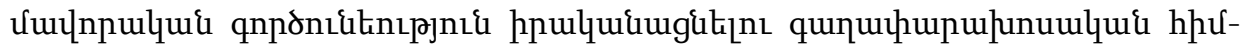

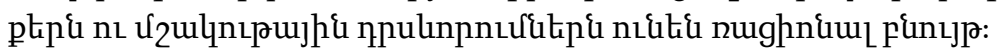

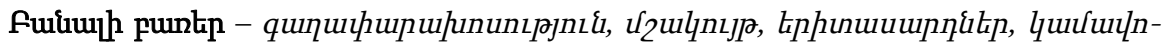

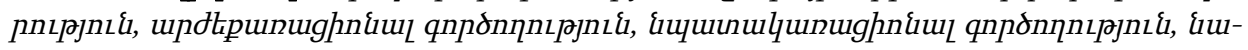
puinhy utuknunhlqu

АРУТЮН ВЕРМИШЯН, ТАТЬЯНА ДАРБИНЯН - Идеологические основы и культурные проявления молодежного волонтерства в Армении. - Цель данного исследования - выявление идеологических и культурных аспектов волонтерской деятельности молодежи. Были сопоставлены концепция социального 
действия М. Вебера и функциональная модель волонтерства. На основе разработанного концептуального подхода на первом этапе исследования с помощью онлайн-опросов были определены наиболее распространенные типы молодых волонтеров в Армении (целерациональный, ценностно-рациональный и гибридный). С представителями каждого типа были проведены качественные интервью с использованием методологии нарративной семиотики, раскрывающие жизненный опыт армянских волонтеров. Нарративы анализировались методом нарративного семиотического анализа. В статье рассматриваются особенности становления гражданского общества и формирования гражданского сознания армянской молодежи, показано, что идеологические основы и культурные проявления ее волонтерской деятельности носят рациональный характер.

Ключевые слова: Идеология, культура, молодежь, волонтерство, ценностнорачиональное действие, челерациональное действие, нарративная семиотика 


\begin{abstract}
The purpose of this study is to identify the ideological and cultural aspects of youth volunteering. The concept of social action by $\mathrm{M}$. Weber and the functional model of volunteering were compared . Based on the developed conceptual approach, at the first stage of the study, using online surveys, the most common types of young volunteers in Armenia (goal-rational, valuerational and hybrid) were identified. High-quality interviews were conducted with representatives of each type using the methodology of narrative semiotics, revealing the life experience of Armenian volunteers. Narratives were analyzed using the method of narrative semiotic analysis. The article examines the peculiarities of the formation of civil society and the formation of civic consciousness of Armenian youth, it is shown that the ideological foundations and cultural manifestations of their volunteer activities are rational in nature.
\end{abstract}

Keywords: Ideology, Culture, Youth, Volunteering, Value-rational Action, Rationallypurposeful Action, Narrative Semiotics

\title{
About Authors
}

Harutyun Vermishyan - PhD, Associate Professor, Head of the Chair of Theory and History of Sociology, Yerevan State University

E mail: harutyunvermishyan@ysu.am

Tatyana Darbinyan - researcher, "Socies" expertise center

E mail: info@socies.am

\section{REFERENCES}

Wilson, J. \& Musick M. A. (1997). Who Cares? Toward an Integrated Theory of Vol-unteer Work, American Sociological Review, Vol. 62, No. 5, 694-713

Wilson, J. (2000). Volunteering, Annual Review of Sociology, 26. Doi:

https://doi.org/10.1146/annurev.soc.26.1.215

Wilson, J. \& Musick M. A. (2008). Volunteers. A Social Profile, Indiana University Press, 217399

Hustinx, L., Cnaan, R. A. \& Handy, F. (2010). Navigating Theories of Volunteering: A Hybrid Map for a Complex Phenomenon, Journal for the Theory of Social Behaviour, 414-418. Doi: https://doi.org/10.1111/j.1468-5914.2010.00439.x

Strauß, S. (2008). Volunteering and Social Inclusion, 1st Edition, Edited by Prof. Dr. Steffen Hillmert, University of Tübingen, Germany. Doi: https://doi.org/10.1111/0022-4537.t01-100027

Piliavin, J. A., Grube J. A. \& Callero P. L. (2002). Role as Resource for Action in Public Service, Journal of Social Issues, Vol. 58, No. 3, 469-485

Salamon, L. M., Sokolowski, S. W. \& List, R. (2003). Global Civil Society: An Overview, John Hopkins Comparative Nonprofit Sector Project

Juknevičius, S. \& Savicka A. (2003). From restitution to innovation: Volunteering in postcommunist countries, in P. Dekker and L. Halman (eds) The values of volunteering: Cross- 
cultural perspectives, New York, NY: Springer, 127-142. Doi: https://doi.org/10.1007/978-14615-0145-9_8

Howard, M.M. (2003). The weakness of civil society in post-communist Europe, Cambridge: Cambridge University Press. Doi: https://doi.org/10.1017/CBO9780511840012

Gevorgyan, V. \& Galstyan M. (2016) Why Volunteer? Understanding Armenia's Experience Voluntary Sector Review. Vol.7. Number 3. Doi:

https://doi.org/10.1332/204080516X14722016138748

Paturyan, Y. \& Gevorgyan V. (2017). Volunteering in Armenia: Leaving the Soviet Legacy Behind? in Butcher J. \& Einolf Ch. J. (Ed.) Perspectives on Volunteering: Voices from the South: Springer, 227-244. Doi: https://doi.org/10.1007/978-3-319-39899-0_12

Paturyan Y. \& Gevorgyan V. (2014). Trust towards NGOs and volunteering in South Caucasus: civil society moving away from post-communism? Southeast European and Black Sea Studies, 14:2, 239-262. Doi: https://doi.org/10.1080/14683857.2014.904544

Wright, E.O. (2002). Sociology 298, Lecture 11: Class Analysis of Ideology, Retrieved from https://www.ssc.wisc.edu/ wright/SOC621/298lec11.pdf

Weber, M. (1956). The Nature of Social Action, Economy and Society 4th edn, Tubingen, First published in 1922

Hustinx, L., Cnaan, R. A. \& Handy, F. (2010). Navigating Theories of Volunteering: A Hybrid Map for a Complex Phenomenon, Journal for the Theory of Social Behaviour, 413. Doi: https://doi.org/10.1111/j.1468-5914.2010.00439.x

Clary, E. G., Snyder, M. \& Stukas, A. A. (1996). Volunteers’ Motivations: Findings from a National Survey Nonprofit and Voluntary Sector Quarterly, 485-505. Doi:

https://doi.org/10.1177/0899764096254006

Clary, E. G., Snyder, M., Ridge, R. D., Copeland, J., Stukas, A. A., Haugen, J. \& Miene, P. (1998). Understanding and Assessing the Motivations of Volunteers: A Functional Approach.

Doi: https://doi.org/10.1037/0022-3514.74.6.1516

Clary, E. G. \& Snyder, M. (1999). The Motivations to Volunteer: Theoretical and Practical

Considerations, Current Directions in Psychological Science, Vol. 8, No. 5, 156-159. Doi: https://doi.org/10.1111/1467-8721.00037

Greimas, A. J. (1987). On Meaning: Selected Writings in Semiotic Theory, Theory and History of Literature, Volume 38, University of Minnesota Press, Minneapolis

Greimas, A.J. (2004). Strukturnaya semantika. Poisk metoda. Moscow. Akademicheskii proekt. $25-42$

Titscher, S., Meyer, M., Wodak, R. \& Vetter, E. (2000). Methods of Text and Discourse Analysis, Sage, 126

Fiol, M. C. (1989). A Semiotic Analysis of Corporate Language: Organizational boundaries and Joint Venturing, Administrative Science Quarterly, Vol. 34, No 2, 277-303. Doi: https://doi.org/10.2307/2989899

Wilson, J. \& Musick, M. A. (2008). Volunteers. A Social Profile, Indiana University Press, 65 